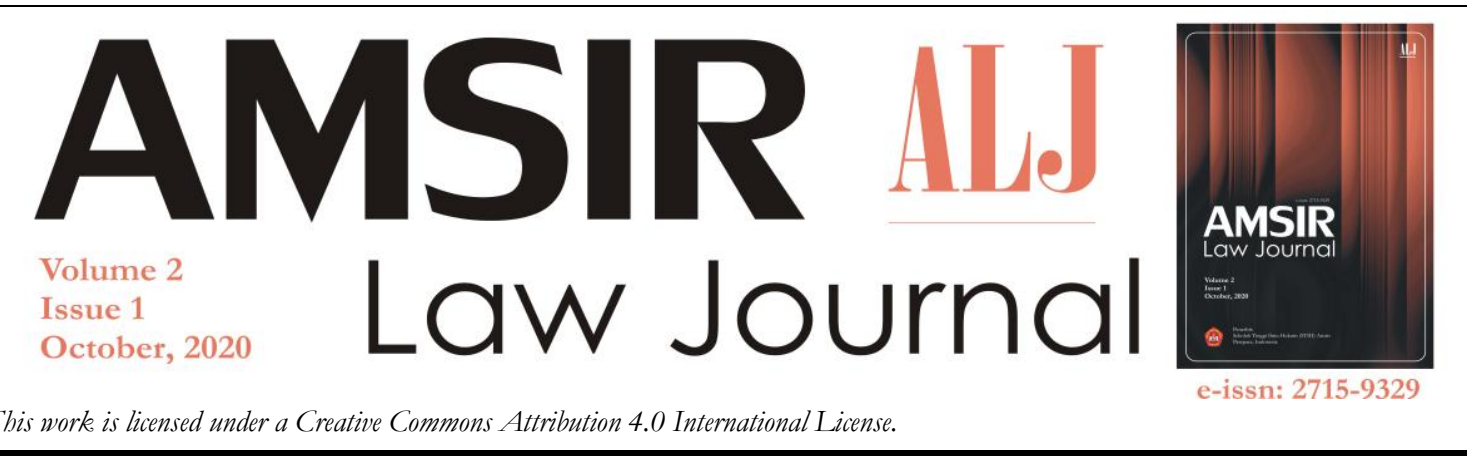

\title{
The Effects of Monism and Pluralism on Legal Development of a Nation
}

\author{
Sunardi Purwanda, ${ }^{1}$ Mira Nila Kusuma Dewi ${ }^{2}$
}

\begin{tabular}{l} 
ARTICLE INFO \\
\hline Keywords: \\
Philosophy, Monism, Pluralism, \\
Legal Development, Nation. \\
How to cite: \\
Purwanda, Sunardi., and \\
Dewi, Mira Nila Kusuma. \\
(2020). The Effects of \\
Monism and Pluralism on \\
Legal Development of a \\
Nation. Amsir Law Journal, \\
2(1), 21-26. \\
DOI: \\
10.36746/ alj.v2i1.30
\end{tabular}

\section{Introduction}

\begin{abstract}
This study demonstrates the impacts of monism and pluralism on the legal development of a nation. First of all, this study discusses how isms or sects or ideologies begin, related to supernatural thoughts by humans. Subsequently, these thoughts develop into a concept that nature is the center of this universe. Nature sign is not due to supernatural power or in other words rain falls not because the Rainy Goddess is crying but nature itself moves its power. Nature supreme grows well in human knowledge, through natural studies, which is called naturalism. Naturalism continuously forms materialism, something that presents/exists, and then it is what is called the truth. Next, these thoughts develop to mechanistic and vitality thoughts. These give impacts to culture, social even legal system in a nation.
\end{abstract}

Copyright (C) 2020ALJ. All rights reserved.

Humans on this earth have not understood themselves as complete humans. Even Sigmund Freud did not either. ${ }^{3}$ Humans sometimes confuse themselves. Indeed, how humans are confused with themselves, is called philosophy.

Humans need philosophizing to solve their confusedness. It is to find out about themselves, this universe, even to a higher level, to finding of God. The more curious a human is-to himself, nature and God-the more a human curious to find the meaning of this life. Human will approach fundamental questions such as: Who are you? What for you are created?, Where will you go? These questions will continue to revolve in the human ratio: what is the answer?; how to answer it?

1 STIH Amsir, Indonesia. E-mail: sunardipurwandaa@gmail.com

2 Fakultas Hukum, Universitas Indonesia Timur, Indonesia.

3 The father of psychoanalysis. Half of his life deepens the human soul. He concluded: women are very difficult to understand. 
Humans are unique, equipped with a ratio to guess the questions he caught/received. Aristotle declared humans as animal rationales: intelligent animals! ${ }^{4}$ While the popular phrase of Rene Descartes shows that human existence originates from the mind, cogito ergo sum: I think, then I exist.

Humans are the most perfect creatures among others who inhabit this earth. They are given reason and feeling, to determine good and bad as well as right and wrong. A balanced mix, isn't it? Regarding this, described by Leonardo da Vinci, a human whom he calls human Vitruvius, is full of balance. The human balance intended by Leonardo da Vinci is a balance that follows the geometric pattern that was written by Vitruvius. ${ }^{5}$

Beyond feeling, the mind is the key for humans to understand their selfhood as humans, the vast universe, and the Creator. Doubts will be slightly eroded by human thoughts and contemplation. Beyond feeling, the mind is the key for humans to understand their selfhood as humans, the vast universe, and the Creator. Doubts will be slightly eroded by human thoughts and contemplation. Thinking is one of the peculiarities of humans compared to other creatures. Therefore, human beings in their existence can understand that they can act as subjects and objects from their own observations. ${ }^{6}$

Humans depart from a sense of curiosity that is so great. Humans question their origins, what creates them, and where they want to go later. This curiosity then makes people find out the source.

Similar to the fundamental question W. S. Rendra in the prologue of the book Daulat Manusia, the work of Thomas Paine: Humans make observations to nature, are the parts of nature? The process of observation takes place continuously, without end. After finding a satisfying answer, humans must again question other possibilities. Curiosity knows until it reaches basic knowledge.

The process is the essence of philosophy. The end product or commonly called a product is not the end of a philosophical process. Products can be renewed, of course, through a new process, a new way of looking at something new. The process is like clockwise, which keeps moving to showtime.

Muhammad Erwin divides time as a medium of proof of philosophy into the following three stages: before occurrence; when it occurs; and after that. ${ }^{7}$ This stage of time can relate to the birth process to human death itself. The period is in the womb nature, worldly nature, and the afterlife.

In a process of philosophizing, not always humans can be in line with other human views. This is what later created the ism, sect or ideology of thought in philosophy. Besides, it also creates tension between thinkers in revealing the truth that they believe.

This ism, sect or ideology then influences the human mindset and/or pattern of view. Not infrequently conflicts often present adorn time and time-space debates. The first philosopher put forward a thesaurus, "chicken first, then egg" and answered by the second philosopher "Oh no, egg first then be chicken." These conflicts often adorn the spaces of

\footnotetext{
${ }^{4}$ Aristotle's logic, mapping definitions according to these two aspects: the closest, and the most specific. Animals are the closest to physical humans, while "specific reason" is a differentiator for distinguishing humans and animals. Snijders, Adelbert. (2004). Antropologi Filsafat: Manusia, Paradoks dan Seruan. Yogyakarta: Kanisius, p. 17.

${ }^{5}$ Vitruvius $( \pm 80-15 \mathrm{SM})$ was a writer from Rome who wrote about visual arts loosely called war architecture. Vitruvius lived in the era of Emperor Augustus. Besides, he also became a soldier when Julius Caesar came to power in Rome.

${ }^{6}$ Erwin, Muhammad. (2016). Filsafat Hukum: Refleksi Kritis terbadap Hukum dan Hukum Indonesia (dalam Dimensi Ide dan Aplikasi). Jakarta: Raja Grafindo Persada, p. 2.

${ }^{7}$ Ibid., p. 5.
} 
scientific discourse; the conflict between scientific schools, even the discussion of the discourse space of the legal sciences.

\section{Method}

This study aimed to understand the effects of monism and pluralism on the legal development of a nation. The research method used in this research is a normative approach, supported by various library materials, such as reading literature in the form of philosophy books, philosophical journals, articles in online media, and papers. The use of the study focuses more on comparative studies by prioritizing the dialectical process. Its use is applied among the objects of study: monism and pluralism.

Besides, the discussion in this paper will be systematically compiled, in line with the general scientific norms. But in this paper, later the author does not provide an assessment or not in the capacity to assess one object of study, for example, one is superior to the other. The author only concentrates on describing the two streams that are the object of study in this paper.

\section{Philosophy and Knowledge}

In the book Philosophy of Science written by Jujun S. Suriasumantri, philosophy and science are likened to a military unit, philosophy is that the marines are science is the infantry force.

In seizing an island, the first time deployed was a marine force; the point was to secure the coastal and coastal areas. After the coastal and coastal areas are safe, then infantry forces will be deployed to take control of the mainland, not only mastering but also building barracks, road bridges, and so on. Likewise, with philosophy and science, philosophy opens the horizons of knowledge, opens the door, is the science which then executes knowledge, makes the living room, sleep, and eat. ${ }^{8}$

\subsection{Relation Between Philosophy and Knowledge}

In the 1920s, there was a great change in interest in humans in science. This great interest is intended to reflect science critically. This change in interest is influenced by the development of human life, the characteristics shown in the change in interest are: Increasingly scientific knowledge of human life in all fields; Growth towards managerial society; Growth of the democratization process; Shifting values and crises in the field of morality; Cultural lag, social conflict, ideological conflict; Great power given to human knowledge; Structural shift in power relations at the international level. ${ }^{9}$

The tendency of interest above is born of philosophy, present from deep contemplation. A process of contemplation that for Lili Rasjidi is not daydreaming or thinking by chance which is chancy. ${ }^{10}$ The philosophy departed from ignorance of knowing, which then moved on to knowledge, from that knowledge turned into knowledge.

Philosophy is a critical reflection, different from science directly related to the real world or the world of experience (empirical world). Philosophy requires a process of

\footnotetext{
8 This presumption was introduced by Will Durant in his book The Story of Philosophy. Suriasumantri, Jujun S. (2003). Filsafat Ilmu: Sebuah Pengantar Populer. Jakarta: Pustaka Sinar Harapan, p. 22.

9 Polak, Fred L. "Om Het Behoud van Ons Bestaan” on Bernard Arief Sidharta. (2000). Refleksi tentang Struktur Ilmu Hukum: Sebuah Penelitian tentang Fundasi Kefilsafatan dan Sifat Keilmuan Ilmu Hukum sebagai Landasan Pengembangan Ilmu Hukum Nasional Indonesia. Bandung: Mandar Maju, p. 13.

${ }^{10}$ Rasjidi, Lili. (1990). Dasar-dasar Filsafat Hukum. Bandung: Citra Aditya Bakti, p. 5.
} 
reflection, namely reflection and deepening of the meanings and meanings experienced critically and rationally. ${ }^{11}$

Every definitive knowledge is classified as science and every dogma is classified in the field of theology. Among the theology and science there lies a continent, without owners, "no man's land" said Russell and on the continent the owner is the philosophy enthroned. ${ }^{12}$

\subsection{Philosophy as a Science}

Philosophy is the mother of science, so is the view of Shidarta, the former chairman of the teaching association of the philosophy of Indonesian law said. ${ }^{13}$ According to him, the characteristics of science include these four elements: certain objects, systematic, methodical, and universally acceptable.

Basically, science is part of philosophy, in the form of small layers that come into contact with other small layers. Science as a part of philosophy is very feasible to be tested for its truth, given the nature of science which is indeed open to study. Karl Popper said when science is not tested it is the same as religion.

Philosophy has both material and formal objects. The material object of philosophy is everything that exists and may have something to do with reality. Whereas the formal object is the point of view in carrying out contemplation, in a holistic, integral, radical, reflective manner that reaches the essence of something. Methodically, philosophy accommodates and uses all methods of research in all sciences.

Philosophy also means the existence of universality in science. The truth of philosophical answers is greatly influenced by how true something can be logically accepted or reasonable. This is what Jujun S. Suriasumantri intended later as the possibility of recognizing various existing knowledge such as science, art, and religion and putting them in their respective places that enrich our lives.

\subsection{Isms in Philosophy}

Ism or sects or ideology is the result of a process of philosophizing, but still temporary, and not final. This ism then makes philosophical discourse richer, more open to be questioned, criticized and even debated.

The beginning of the ism is caused by the human perspective in observing nature. Interpretation of nature was first conveyed by humans to the presence of something supernatural, which is more powerful, more dominant than nature. According to Jujun $\mathrm{S}$. Suriasumantri, animism is a belief based on supernaturalism. In fact, it is the oldest of all thoughts on human belief in this world. Humans believe that there are spirits that are supernatural and are contained in objects such as rocks, trees, and waterfalls. ${ }^{14}$ This is then known as paganism, superstitious people.

Then a thought develops, that nature is the center of this universe. Symptoms of nature are not caused by supernatural powers, or rain falls not because the rain goddess cries anymore, but nature itself moves its power. Natural sovereignty thrives on human knowledge, through natural learning, called naturalism. It is this understanding of naturalism which then shapes materialism, what appears/exists then that is the truth.

\footnotetext{
${ }^{11}$ Roestandi, Achmad. (1987). Responsi Filsafat Hukum. Bandung: Armico, p. 9.

12 Bawengan, G. W. (1983). Sebuah Studi tentang Filsafat. Jakarta: Pradnya Paramita, p. 7.

${ }^{13}$ In a meeting in the Science Philosophy class, Master of Law Program Universitas Diponegoro.

${ }^{14}$ Suriasumantri, Jujun S. Op. Cit., p. 64.
} 
This thinking then develops, develops, and develops again. Continue to experience development in the mechanistic and vitalistic stages. The mechanistic ism of seeing natural phenomena is only a symptom of chemistry-physics. As for vitalistic ism, life is something unique and substantively different from the above process. ${ }^{15}$ From these two things which then build the next discourse, parse several subsequent understandings and isms, including Monism and Pluralism.

The monism emphasizes the view that the universe is a single entity, matter, and one mind. As stated by Stanley M. Honer and Thomas C. Hunt, that mind and matter are one, which differs only in terms of the symptoms caused by the process. So according to him, the thought process is the electrochemical activity of the brain, ${ }^{16}$ while the pluralism holds the view of distinguishing between the matter and the realm of mind, or matter and mind/consciousness. Substantively, they are different from generic. This ism maps between materialism and idealism, as something that cannot be put together.

\section{The Effects of Monism and Pluralism on Legal Development of a Nation}

Most of the views or schools of monism in this paper were pioneered by early (first) philosophers. The attention of the early philosophers was focused on the natural view, their attention devoted to nature. Events such as daytime change of the night, cold to hot, the sun turn into the moon, become the focal point of philosophers in looking at the universe. As for the understanding or ism of pluralism, the truth is that understanding is present after the ism of monism flourishes. The notion or ism of pluralism was born because of the rejection of the idea of the monism ism. The characters believe, not only natural phenomena that must be observed but also change and social dynamics of society. Like there is a transition of study objects, from nature to society. Both of these views or streams, look at the universe as the object of study, although the final result is different.

The results of the investigation into the views of philosophers of monism may be summed up in the following five scopes: First, the universe is a unified whole, the result must be explained by one principle only; The universe is dominated by law, namely natural law; Second, events that take place in nature do not just happen, but some regulate them; Third, the universe is a cosmos or an orderly, chaotic world; Fourth, the monism philosophers put forward the aspect ratio/logos in capturing all the events that took place in nature; And fifth, what exists is singular, not plural let alone plural.

As for the results of the investigation on the views of philosophers of pluralism, it might be concluded in the following five scopes: First, not willing to sacrifice sensory testimony. However the senses are one of the important elements in looking at the reality of truth that exists in the universe; Second, the reality consists entirely of many principles, not just one element; Third, it is still influenced by some opinions of the monism line, although on some sides there are observations of the ism of monism that has been broken; Fourth, the tendency to build two methods of discovery of truth, through reason and also sensory, as a form of improvement in the results of truth; And fifth, there is a shift in the object of study, from the universe to society.

In the teachings of monism, the development of the law of a country is directed at a single, both its power, and the powers possessed by the ruler. The doctrine of monism fosters an absolute monarchy, a system of empires in which its rulers are a king, and the law that is present in it is a form of the legitimacy of a single/king power.

${ }^{15}$ Suriasumantri, Jujun S. Ibid., p. 66.

${ }^{16}$ Honer, Stanley M., \& Hunt, Thomas C. (1968). Invitation to Philosophy. Cal: Wadsworth, p. 78. 
Whereas the teachings of pluralism see the development of a country in a plural form. Power and authority are divided into the amount needed. This teaching prioritizes democratic society/pluralism, this certainly fosters the republic's system, led by community representatives, and the law that is born is a form of desire from what society wants to achieve.

\section{Conclusion}

Monism focuses more on one, single view, in looking at the main source of this universe. Meanwhile, pluralism sees it as a form of diversity (plural), consisting of several elements. These two schools shaped the thinking of individuals and society at that time, in which the tendency of monism to be more towards a monarchical form of government whose legal concept was born from the wishes of the king, while the flow of pluralism promoted a democratic society/plural with various legal features.

\section{Acknowledgments}

We thank the editorial team of Amsir Law Jurnal for publishing our article in volume 2 (1), October 2020.

\section{References}

Books with an author:

Bawengan, G. W. (1983). Sebuah Studi tentang Filsafat. Jakarta: Pradnya Paramita.

Erwin, Muhammad. (2016). Filsafat Hukum: Refleksi Kritis terhadap Hukum dan Hukum Indonesia (dalam Dimensi Ide dan Aplikasi). Jakarta: Raja Grafindo Persada.

Honer, Stanley M., and Hunt, Thomas C. (1968). Invitation to Philosophy. Cal: Wadsworth.

Polak, Fred L. "Om Het Behoud van Ons Bestaan" on Bernard Arief Sidharta. (2000). Refleksi tentang Struktur Ilmu Hukum: Sebuah Penelitian tentang Fundasi Kefilsafatan dan Sifat Keilmuan Ilmu Hukum sebagai Landasan Pengembangan Ilmu Hukum Nasional Indonesia. Bandung: Mandar Maju.

Rasjidi, Lili. (1990). Dasar-dasar Filsafat Hukum. Bandung: Citra Aditya Bakti.

Roestandi, Achmad. (1987). Responsi Filsafat Hukum. Bandung: Armico.

Snijders, Adelbert. (2004). Antropologi Filsafat: Manusia, Paradoks dan Seruan. Yogyakarta: Kanisius.

Suriasumantri, Jujun S. (2003). Filsafat Ilmu: Sebuab Pengantar Populer. Jakarta: Pustaka Sinar Harapan.

\section{Conflict of Interest Statement:}

The author declares that the research was conducted in the absence of any commercial or financial relationships that could be construed as a potential conflict of interest.

Copyright (C) 2020 ALJ. All rightsreserved. 